\title{
INTEGRASI SIKAP MULTIATRIBUT FISHBEIN DAN HOUSE OF QUALITY DALAM MENINGKATKAN DAYA SAING JERUK LOKAL (CITRUS SP)
}

\section{Integration of Fishbein's Multi-Attribute Attitude and House of Quality in Improving Competitiveness of Local Orange (Citrus sp)}

\author{
Wilson Kosasih ${ }^{1 *}$, Iphov K. Sriwana ${ }^{2}$, Frans J. Daywin ${ }^{1}$, Vera Veliria ${ }^{1}$, Lithrone L. Salomon ${ }^{1}$ \\ 1 Program Studi Teknik Industri - Fakultas Teknik - Universitas Tarumanagara \\ Jl. Letjen S. Parman No. 1 - Jakarta 11440 \\ 2Program Studi Teknik Industri - Fakultas Rekayasa Industri - Universitas Telkom \\ Jl. Telekomunikasi Terusan Buah Batu No.1 - Bandung 40257 \\ Penulis Korespondensi, email: wilsonk@ft.untar.ac.id
}

Disubmit : 7 Juni 2020 Direvisi : 18 Februari $2021 \quad$ Diterima : 16 April 2021

\begin{abstract}
ABSTRAK
Indonesia merupakan salah satu negara penghasil buah jeruk (Citrus $s p$ ) terbesar, yaitu mencapai 2563490 ton pada tahun 2019, meskipun demikian faktanya buah jeruk merupakan salah satu komoditas hortikultura impor utama. Kehadiran jeruk impor sebagai kompetitor membuat keberadaan jeruk lokal tergeser sehingga perlu adanya rencana strategis yang membuat jeruk lokal lebih diminati konsumen. Penelitian ini bertujuan untuk mengidentifikasi atribut yang dominan berpengaruh pada buah jeruk, daya saing jeruk lokal berdasarkan sikap konsumen, faktor-faktor yang mempengaruhi daya saingnya, dan juga mengembangkan rencana strategi peningkatan daya saing jeruk lokal. Penelitian ini menggunakan metode survei dengan pendekatan model sikap Fishbein, dimana pada prinsipnya sikap seseorang terhadap sebuah objek akan dikenali lewat atribut-atribut yang melekat pada objek tersebut. Responden dalam penelitian ini dipilih secara purposive sampling yaitu penetapan responden berdasarkan kriteria pernah membeli dan mengonsumsi jeruk baik lokal maupun impor, umur responden minimal 16 tahun dan berdomisili di Jakarta. Hasil studi ini mendemonstrasikan bahwa sikap konsumen pada buah jeruk lokal menunjukkan bahwa keputusan konsumen di Jakarta untuk membeli atau mengkonsumsi buah jeruk lokal didasarkan pada ketertarikan karena harga, ketersediaan, kandungan air dan kesegaran. Secara keseluruhan jeruk impor lebih positif di mata konsumen ditunjukkan dengan 6 dari 10 atribut jeruk impor lebih unggul dibanding jeruk lokal. Pada akhirnya, tindakan rekomendasi yang diprioritaskan untuk jeruk lokal diperoleh dari hasil House of Quality (HOQ) terhadap lima atributnya yang memiliki kualifikasi sedang dan buruk, yaitu aroma, warna, tampilan fisik, kemasan dan merek.
\end{abstract}

Kata kunci: Atribut; Daya Saing; Fishbein; HOQ; Jeruk

\section{ABSTRACT}

Indonesia is one of the largest oranges (Citrus sp) producing countries, reaching 2563490 tonnes in 2019, despite the fact that fresh orange is one of the main imported horticultural commodities. The presence of imported oranges as a competitor displaced the local oranges, so that a strategic plan was needed to make local oranges more attractive to consumers. This research study aims to identify the attributes that have a dominant effect on orange, the competitiveness of local oranges based on consumer attitudes, the factors that affect their competitiveness, and also develop a strategic plan to increase the competitiveness of local oranges. This study was conducted using a survey method with the Fishbein attitude model approach, where in principle a person's attitude towards an object will be recognized through the attributes attached to the object. Respondents in this study were selected by purposive sampling, namely the determination of respondents based on the criteria of having bought and consumed oranges both local and imported, with at 
Jurnal Teknologi Pertanian Vol. 22 No. 1 [April 2021] 69-80

Integrasi Sikap Multiatribut Fishbein dan House of Quality dalam Meningkatkan Daya Saing Jeruk Lokal [Kosasih dkk]

least 16 years of age and domiciled in Jakarta. The results of this study demonstrate that consumer attitudes towards local oranges indicate that consumer decisions in Jakarta to buy or consume local oranges are based on attractiveness due to price, availability, water content and freshness. Overall, imported oranges are more positive in the points of consumers, indicated by 6 out of 10 attributes of imported oranges being superior to local oranges. In the end, the recommended actions that were prioritized for local oranges were obtained from the results of the House of Quality (HOQ) of its five attributes which had moderate and poor qualifications, namely aroma, color, physical appearance, packaging and brand.

Keywords: Attribute; Competitiveness; Fishbein; HOQ; Orange

\section{PENDAHULUAN}

Indonesia dikenal sebagai negara agraris dan memiliki tanah yang subur sehingga memungkinkan potensi tumbuhnya berbagai jenis tanaman buah-buahan termasuk buah jeruk (Citrus sp). Indonesia sendiri merupakan negara peringkat ke-8 penghasil jeruk terbesar setelah Mesir dengan total produksi pada tahun 2016, 2017, 2018, 2019 berturut-turut mencapai 2138474 ton, 2538173 ton, 2510442 ton dan 2563490 ton (Badan Pusat Statistik, 2019). Nilai produksi tersebut mencakup semua jenis jeruk, mulai dari jeruk manis, siam, keprok, dan pomelo. Faktanya buah jeruk banyak diimpor. Kehadiran jeruk impor sebagai kompetitor membuat keberadaan jeruk lokal tergeser sehingga perlu adanya rencana strategi untuk meningkatkan minat konsumen terhadap jeruk lokal.

Menurut Sunarjono (2015), Indonesia pernah tercatat sebagai negara pengimpor jeruk terbesar kedua di ASEAN setelah Malaysia dengan volume jeruk segar impor sebesar 96349 ton, sedangkan ekspornya hanya sebesar 71 ton dengan tujuan ke Malaysia, Brunei Darusalam, dan Timur Tengah. Menurut Badan Pusat Statistik (2019), nilai ekspor jeruk sebesar US\$ 653000 dan nilai impor jeruk sebesar US\$219340000. Volume jeruk segar yang diimpor pada tahun 2019 sebesar 118059 ton dengan rincian negara asal Cina 68770 ton, Pakistan 28137 ton, Australia 7691 ton, dan lainnya 13461 ton.

Berbeda dengan Jawa Timur, Bali dan Sumatera Utara yang merupakan basis produksi jeruk terbesar di Indonesia (Badan Pusat Statistik, 2019), Jakarta menjadi salah satu wilayah tujuan akhir distribusi pemasaran buah jeruk lokal maupun impor. Oleh karena itu, penelitian ini difokuskan di wilayah DKI Jakarta untuk mengukur sikap konsumen terhadap atribut buah jeruk dengan menggunakan model sikap Fishbein yang selanjutnya diintegrasikan dengan matrix House of Quality (HOQ). Penelitian ini bertujuan untuk mengidentifikasi atribut yang dominan berpengaruh pada buah jeruk, daya saing jeruk lokal berdasarkan sikap konsumen, faktorfaktor yang mempengaruhi daya saingnya, dan juga mengembangkan rencana strategi peningkatan daya saing jeruk lokal.

Sikap merupakan presdisposisi (keadaan mudah terpengaruh) yang dipelajari untuk menanggapi secara konsisten terhadap suatu objek, baik dalam bentuk tanggapan positif maupun tanggapan negatif (Ajzen dan Fishbein, 1973; Fishbein dan Ajzen, 1975). Puspita dan Nugrahani (2014) mengungkapkan bahwa konsep sikap sangat berkaitan dengan konsep kepercayaan (belief) dan perilaku (behavioral). Model sikap Fishbein pada prinsipnya akan menghitung attitude toward the object, yaitu sikap seseorang terhadap sebuah objek, yang dikenali lewat atribut-atribut yang melekat pada objek tersebut (Ajzen dan Fishbein, 1973; Widiyanti, 2019). Pengenalan objek melalui cara melihat, meraba, mencoba dan menggunakan objek itu untuk sekian waktu lamanya, maka seorang konsumen akan mempunyai sikap tertentu terhadap objek yang dipakai atau digunakannya tersebut. Menurut Sasmaya et al. (2019), analisis sikap multiatribut dapat menjadi sumber yang kaya akan informasi yang berguna bagi perencanaan dan tindakan pasar. Selain itu, analisis sikap multiatribut juga bermanfaat dalam pengembangan suatu produk baru. Konsumen melihat sebuah produk sebagai sekumpulan atribut (bundle of attributes) dengan kemampuan yang berbeda-beda untuk setiap produk. Tingkat kinerja produk dapat diukur atau dilihat pada tingkat kepentingannya berdasarkan atribut-atribut kunci yang sudah diidentifikasi oleh konsumen (Sadeli dan Utami, 2013). Keputusan mengenai atribut 
produk merupakan unsur-unsur produk yang dipandang penting oleh konsumen dan dijadikan dasar dalam keputusan pembelian (Munandar et al., 2004; Setyanto et al., 2017).

\section{METODE}

Pertama-tama dalam studi ini, ditentukan atribut apa yang dianggap mempengaruhi daya saing jeruk lokal di mata konsumen. Atribut tersebut diperoleh melalui studi lapangan dan studi pustaka. Studi lapangan menghasilkan atribut-atribut pokok yang berpengaruh yaitu rasa, kesegaran dan harga. Studi pustaka dilakukan dengan mempelajari dan menela'ah penelitian sebelumnya.

Penelitian yang dilakukan oleh Felixs dan Palit (2013) mengemukakan atribut-atribut dalam membeli buah tropis nasional dan buah impor yaitu ukuran buah, bentuk buah, warna buah, rasa buah, dan kehigienisan buah, aroma buah, crispiness dan juiciness. Felixs dan Palit (2013) menganalisis tiga jenis buah-buahan yaitu apel, jeruk dan pisang. Atribut-atribut yang menjadi pertimbangan buah jeruk yaitu ukuran, warna, bentuk, kehigienisan, rasa, aroma, dan juiceness. Studi ini juga mempertimbangkan hasil penelitian oleh Yosini (2011), dimana mengemukakan atributatribut dari buah-buahan di Indonesia seperti yang dapat dilihat pada Gambar 1. Yosini (2011) meneliti 12 atribut terhadap buah apel, jeruk dan mangga, dan atribut yang dinilai sangat penting untuk jeruk merupakan rasa dan aroma. Berdasarkan pertimbanganpertimbangan tersebut maka atribut-atribut yang digunakan dalam penelitian ini adalah rasa $(\mathrm{X} 1)$, aroma $(\mathrm{X} 2)$, warna $(\mathrm{X} 3)$, kesegaran (X4), kandungan air (X5), harga (X6), tampilan fisik (X7), kemasan (X8), merek (X9), dan ketersediaan buah (X10).

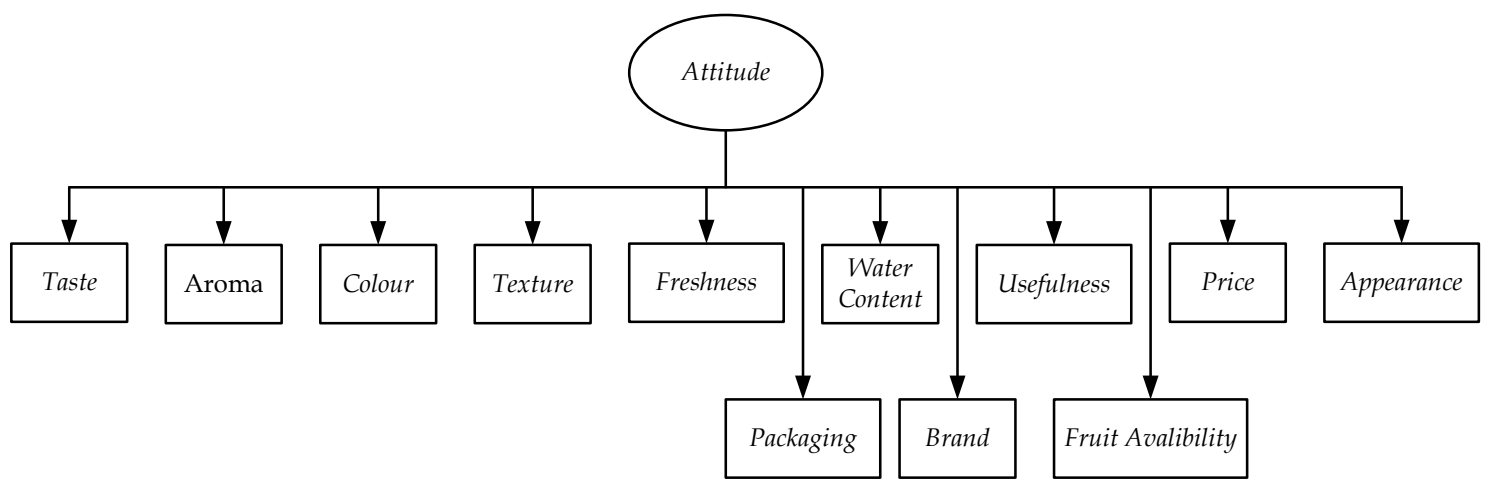

Gambar 1. Atribut buah-buahan di Indonesia (Yosini, 2011)
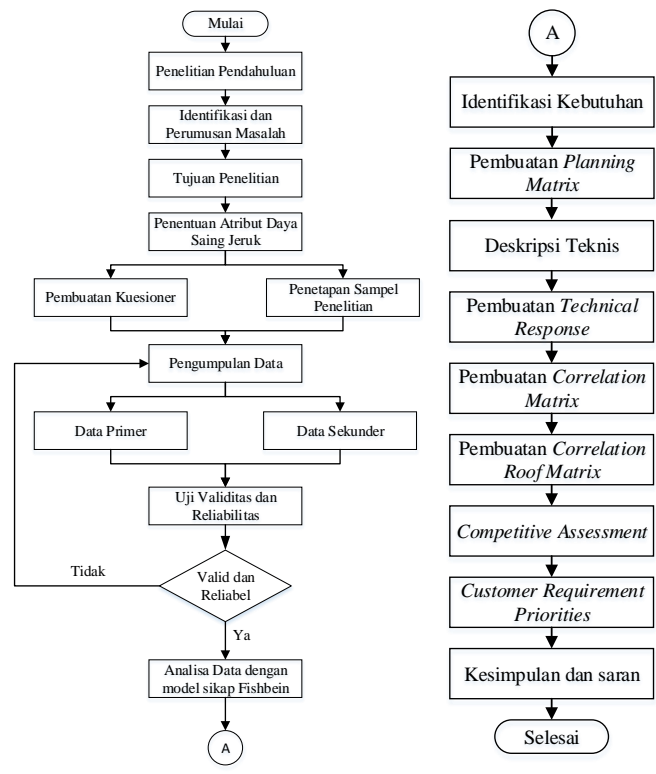

Gambar 2. Diagram alir metode penelitian
Tahapan penelitian yang dilakukan disajikan pada diagram alir yang ditunjukkan pada Gambar 2. Data yang dikumpulkan dalam penelitian ini dibagi menjadi dua yaitu data primer dan data sekunder. Data primer dalam penelitian ini diperoleh dari hasil survei menggunakan kuesioner. Kuesioner penelitian didesain sedemikian rupa mencakup (1) Instruksi pengisian; (2) Pertanyaan karakteristik responden; (3) Pertanyaan pendahuluan; (4) Pertanyaan Fishbein untuk 10 atribut. Instruksi pengisian menjelaskan cara responden dalam mengisi pertanyaan Fishbein yang dibuat dalam bentuk skala penilaian yang mengacu pada skala Likert. Responden mengisi pertanyaan Fishbein pada bagian evaluasi dengan memberikan tanda $(X)$ pada skala rating yang ditentukan dimana angka 1 menunjukkan "sangat tidak penting", dan angka 4 menunjukkan "sangat penting". Sama dengan 
Jurnal Teknologi Pertanian Vol. 22 No. 1 [April 2021] 69-80

Integrasi Sikap Multiatribut Fishbein dan House of Quality dalam Meningkatkan Daya Saing Jeruk Lokal

[Kosasih dkk]

pertanyaan Fishbein pada bagian evaluasi, pertanyaan untuk tingkat kepercayaan diisi dengan memberikan tanda $(X)$ pada skala rating yang ditentukan dimana angka 0 menunjukkan "tidak tahu", angka 1 menunjukkan "sangat tidak setuju", dan angka 4 menunjukkan "sangat setuju". Responden dalam penelitian ini dipilih secara purposive sampling yaitu penetapan responden berdasarkan kriteria pernah membeli dan mengkonsumsi jeruk baik lokal maupun impor, umur responden minimal 16 tahun dan berdomisili di Jakarta. Selain itu, juga mewawancarai pedagang dan pelaku bisnis buah jeruk di Jakarta untuk mendukung data yang diperoleh melalui kuesioner. Data sekunder diperoleh penelitian sebelumnya maupun data dan informasi pertanian frutikultura mengenai data ekspor dan impor jeruk.

Langkah-langkah pengolahan data yang dilakukan dengan terlebih dahulu menguji validitas dan reliabilitas terhadap data responden yang terkumpul menggunakan bantuan perangkat lunak statistik. Pengujian validitas dilakukan dengan membandingkan $r$ hitung untuk tiap atribut yang dapat dilihat pada kolom corrected item total correlation dengan $r$ tabel. Jika $r$ hitung positif, serta $r$ hasil $>\mathrm{r}$ tabel, maka atribut tersebut valid. Pengujian reliabilitas dilakukan dengan membandingkan Cronbach's Alpha dengan $\mathrm{r}$ tabel. Teknik Alpha Cronbach digunakan untuk mengukur reliabilitas bila jawaban responden berbentuk skala. Kriteria suatu instrument dikatakan reliabel dengan menggunakan teknik ini bila koefisien reliabilitas > 0,6 (Siregar, 2013).

Data tersebut selanjutnya digunakan dalam perhitungan model sikap Fishbein attitude toward the object. Dari pengukuran sikap terhadap atribut-atribut jeruk lokal dan jeruk impor dipilih beberapa atribut untuk dilakukan perencanaan strategi peningkatan daya saing jeruk lokal. Menurut Rangkuti (2002), model sikap Fishbein ini mempunyai asumsi bahwa konsumen menggunakan pendekatan standar hierarki efek dimana kepercayaan dapat membentuk suatu sikap. Caranya adalah dengan menghitung nilai sikap $(A B)$ dengan Persamaan (1) (Ajzen dan Fishbein, 1973; Rangkuti, 2002).

$$
A B=\sum_{i=1}^{n}(b i)(e i)
$$

Dimana, $A B$ merupakan sikap total individu terhadap objek tertentu; $b i$ merupakan kekuatan keyakinan konsumen bahwa objek memiliki atribut $i$; ei merupakan evaluasi keyakinan individu mengenai atribut $i$; $n$ merupakan jumlah kriteria atribut yang relevan.

Penentuan rentang skala terhadap setiap indikator atribut produk buah-buahan berdasarkan kriteria mutu produk diidentifikasi menggunakan skala Likert. Penilaian jawaban responden melalui pendekatan skala Likert yang mempunyai alternatif pilihan dari skor 1 sampai 4 . Penentuan rentang skala dengan Persamaan (2) (Sadeli dan Utami, 2013).

$R S=\frac{m-n}{b}$.

Dimana, RS merupakan rentang skala; $m$ merupakan skor tertinggi pada skala; $n$ merupakan skor terendah pada skala; $b$ merupakan jumlah kelas atau kategori.

Atribut-atribut yang terlibat dalam matrix HOQ merupakan atribut yang terkualifikasi sedang dan buruk pada analisis Fishbein. Pembuatan Matrix HOQ dilakukan dengan memasukkan data derajat kepentingan dan derajat kepuasan dari jawaban responden yang telah dianalisa dengan Fishbein dalam bentuk evaluasi dan kepercayaan. Penentuan nilai target dan sales point berdasarkan hasil diskusi dengan pakar. Perhitungan rasio perbaikan (IR) dapat dihitung menggunakan Persamaan (3) (Akao, 1990; Kosasih et al., 2013):

$$
I R=\text { nilai target } \div \text { kinerja kepuasan }
$$

Nilai bobot diperoleh derajat kepentingan dikalikan dengan rasio perbaikan dan dikalikan dengan sales point. Selanjutnya, nilai absolute importance $(A I)$ dan relative importance $(R I)$ diperoleh dari perhitungan menggunakan Persamaan (4) dan (5).

$$
\begin{aligned}
& A I=\Sigma(\text { nilai relationship matrix } \times \text { bobot }) \ldots . .(4) \\
& R I=\frac{\text { Absolute importance }}{\Sigma \text { Absolute importance }} \ldots \ldots \ldots \ldots \ldots \ldots \ldots \ldots
\end{aligned}
$$


Jurnal Teknologi Pertanian Vol. 22 No. 1 [April 2021] 69-80 Integrasi Sikap Multiatribut Fishbein dan House of Quality dalam Meningkatkan Daya Saing Jeruk Lokal

Tabel 1. Demografi karakteristik responden

\begin{tabular}{|c|c|c|c|c|}
\hline \multirow{2}{*}{ No. } & \multirow{2}{*}{ Variabel } & \multirow{2}{*}{ Deskripsi } & \multicolumn{2}{|c|}{ Jumlah $(\mathrm{n}=346)$} \\
\hline & & & Responden & $\%$ \\
\hline \multirow[t]{4}{*}{1.} & Umur & 16-25 tahun & 208 & 60,1 \\
\hline & & 26-35 tahun & 70 & 20,2 \\
\hline & & 36-45 tahun & 33 & 9,5 \\
\hline & & $>45$ tahun & 35 & 10,1 \\
\hline \multirow[t]{2}{*}{2.} & Jenis Kelamin & Laki-laki & 160 & 46,2 \\
\hline & & Perempuan & 186 & 53,8 \\
\hline \multirow[t]{5}{*}{3.} & Pendidikan & SMP & 14 & 4,0 \\
\hline & & SMA & 107 & 30,9 \\
\hline & & Diploma & 27 & 7,8 \\
\hline & & S1 & 191 & 55,2 \\
\hline & & Lainnya & 7 & 2,0 \\
\hline \multirow[t]{6}{*}{4.} & Pekerjaan & Pegawai negeri & 5 & 1,4 \\
\hline & & Karyawan Swasta & 106 & 30,6 \\
\hline & & Wiraswasta & 29 & 8,4 \\
\hline & & IRT & 37 & 10,7 \\
\hline & & Pelajar/mahasiswa & 161 & 46,5 \\
\hline & & Lainnya & 8 & 2,3 \\
\hline \multirow[t]{5}{*}{5.} & Domisili & Jakarta Barat & 122 & 35,3 \\
\hline & & Jakarta Utara & 63 & 18,2 \\
\hline & & Jakarta Pusat & 51 & 14,7 \\
\hline & & Jakarta Timur & 57 & 16,5 \\
\hline & & Jakarta Selatan & 53 & 15,3 \\
\hline \multirow[t]{5}{*}{6.} & Pendapatan per & $<2,5$ juta & 130 & 37,6 \\
\hline & bulan & 2,5 juta - 5 juta & 91 & 26,3 \\
\hline & & 5 juta - 10 juta & 94 & 27,2 \\
\hline & & 10 juta - 20 juta & 23 & 6,6 \\
\hline & & $>20$ juta & 8 & 2,3 \\
\hline \multirow[t]{5}{*}{7.} & Pengeluaran per & $<1,5$ juta & 119 & 34,4 \\
\hline & bulan & 1,5 juta $-2,5$ juta & 92 & 26,6 \\
\hline & & 2,5 juta -5 juta & 87 & 25,1 \\
\hline & & 5 juta - 10 juta & 31 & 9,0 \\
\hline & & $>10$ juta & 17 & 4,9 \\
\hline
\end{tabular}

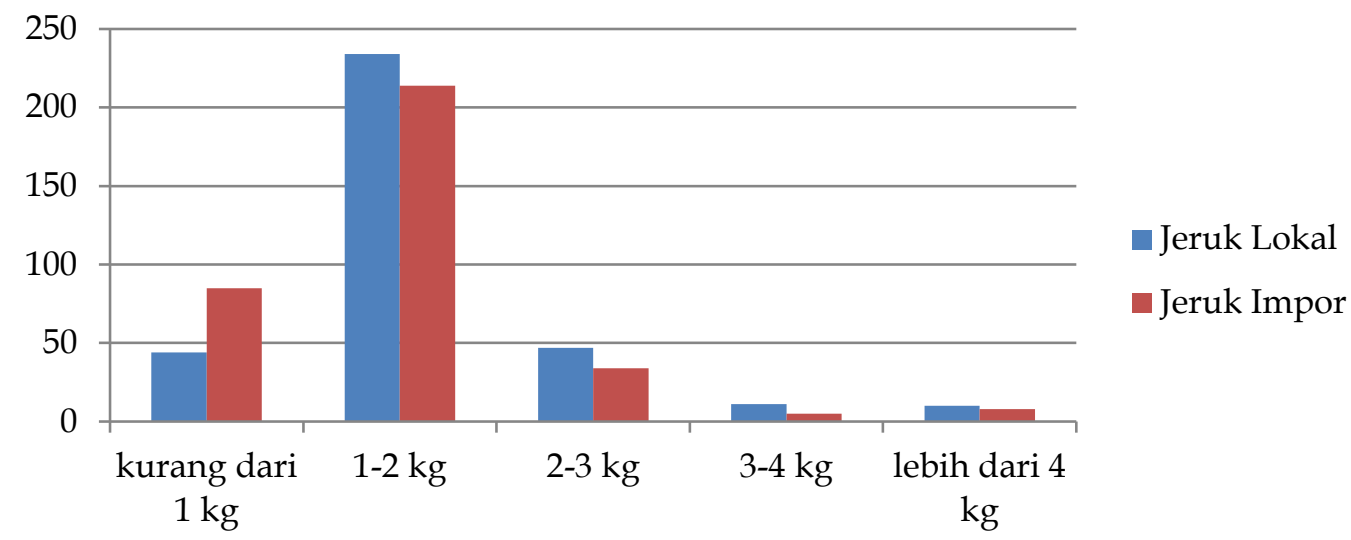

Gambar 3. Jumlah pembelian 
Jurnal Teknologi Pertanian Vol. 22 No. 1 [April 2021] 69-80

Integrasi Sikap Multiatribut Fishbein dan House of Quality dalam Meningkatkan Daya Saing Jeruk Lokal [Kosasih dkk]

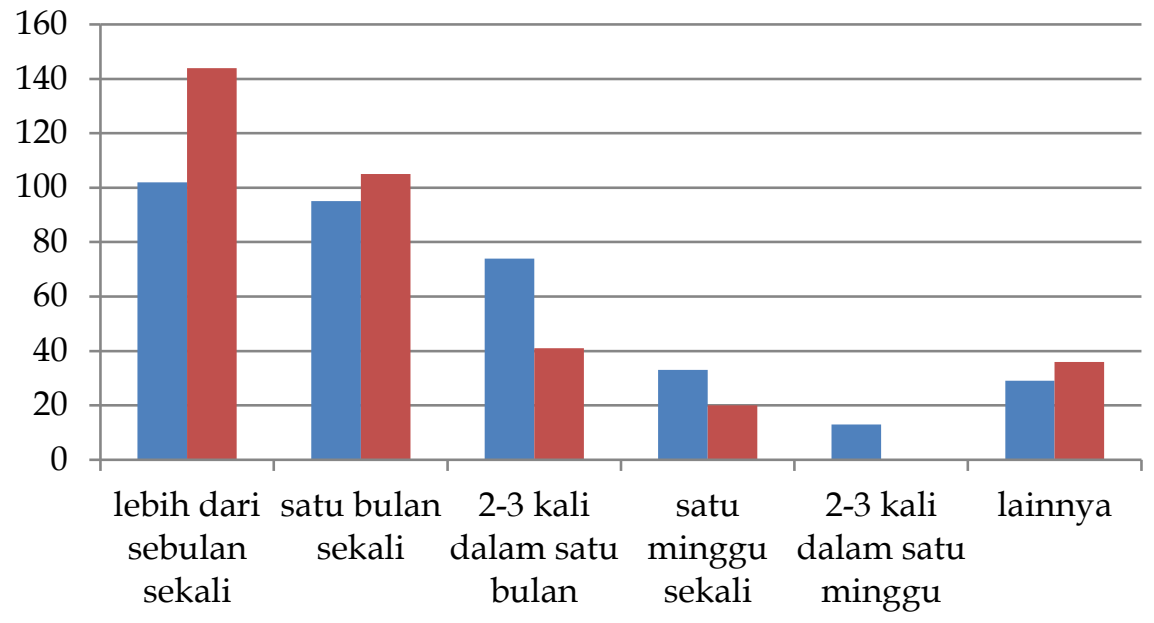

n Jeruk Lokal

- Jeruk Impor

Gambar 4. Frekuensi pembelian

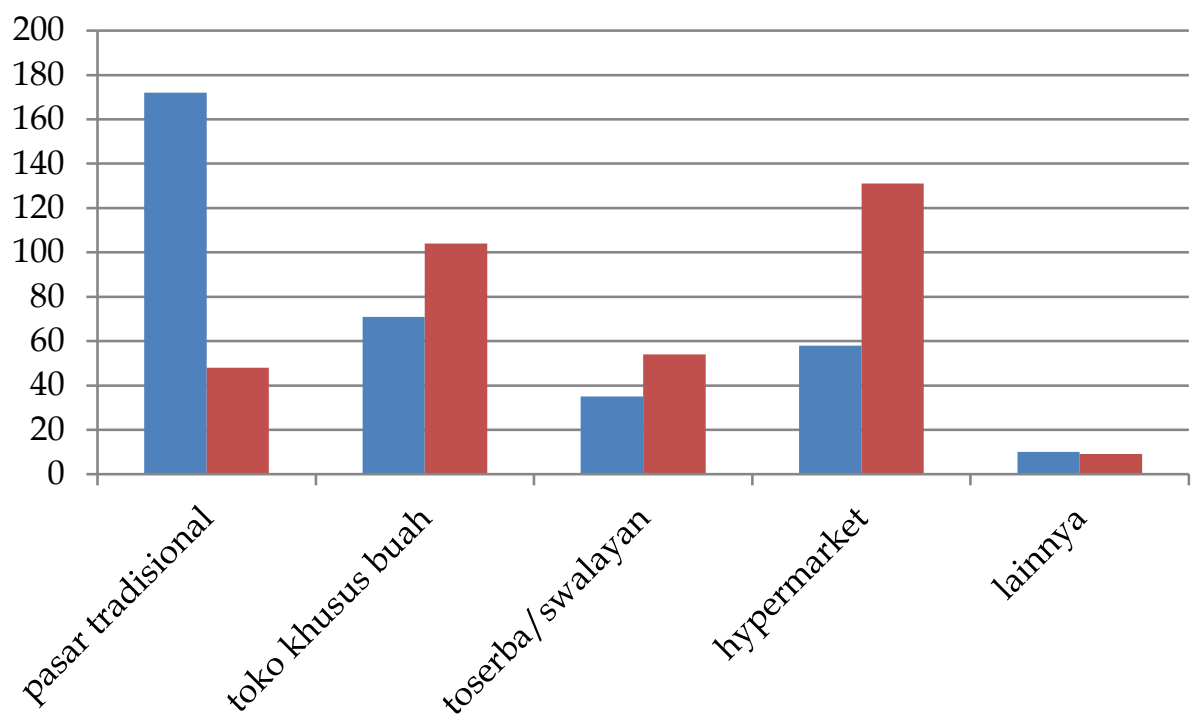

- Jeruk Lokal

n Jeruk Impor

Gambar 5. Lokasi pembelian

Tabel 2. Hasil uji validitas dan reliabilitas dari tiap atribut

\begin{tabular}{cccc}
\hline Atribut & r Tabel & r Hasil & Keputusan \\
\hline X1 & 0,105 & 0,585 & Valid \\
X2 & 0,105 & 0,590 & Valid \\
X3 & 0,105 & 0,612 & Valid \\
X4 & 0,105 & 0,663 & Valid \\
X5 & 0,105 & 0,610 & Valid \\
X6 & 0,105 & 0,469 & Valid \\
X7 & 0,105 & 0,608 & Valid \\
X8 & 0,105 & 0,583 & Valid \\
X9 & 0,105 & 0,452 & Valid \\
X10 & 0,105 & 0,527 & Valid \\
\hline \multicolumn{2}{c}{ r alpha $=0,769$} \\
\hline
\end{tabular}


Jurnal Teknologi Pertanian Vol. 22 No. 1 [April 2021] 69-80 Integrasi Sikap Multiatribut Fishbein dan House of Quality dalam Meningkatkan Daya Saing Jeruk Lokal

[Kosasih dkk]

Tabel 3. Hasil uji validitas dan reliabilitas tingkat kepercayaan jeruk lokal dan impor

\begin{tabular}{cccccccc}
\hline Atribut & r Tabel & r Hasil & Keputusan & Atribut & r Tabel & r Hasil & Keputusan \\
\hline L1 & 0,105 & 0,515 & Valid & I1 & 0,105 & 0,486 & Valid \\
L2 & 0,105 & 0,526 & Valid & I2 & 0,105 & 0,571 & Valid \\
L3 & 0,105 & 0,523 & Valid & I3 & 0,105 & 0,544 & Valid \\
L4 & 0,105 & 0,617 & Valid & I4 & 0,105 & 0,536 & Valid \\
L5 & 0,105 & 0,646 & Valid & I5 & 0,105 & 0,650 & Valid \\
L6 & 0,105 & 0,419 & Valid & I6 & 0,105 & 0,335 & Valid \\
L7 & 0,105 & 0,665 & Valid & I7 & 0,105 & 0,689 & Valid \\
L8 & 0,105 & 0,754 & Valid & I8 & 0,105 & 0,735 & Valid \\
L9 & 0,105 & 0,629 & Valid & I9 & 0,105 & 0,551 & Valid \\
L10 & 0,105 & 0,349 & Valid & I10 & 0,105 & 0,579 & Valid \\
\hline \multicolumn{7}{c}{ r alpha $=0,766$} & Reliabel \\
\hline
\end{tabular}

Keterangan: $\mathrm{L}=$ jeruk lokal; $\mathrm{I}=$ jeruk impor

Tabel 4. Hasil evaluasi dan kepercayaan terhadap Atribut

\begin{tabular}{|c|c|c|c|c|}
\hline \multirow{2}{*}{ No. } & \multirow{2}{*}{ Atribut } & \multirow{2}{*}{ Evaluasi } & \multicolumn{2}{|c|}{ Kepercayaan } \\
\hline & & & Jeruk Lokal & Jeruk Impor \\
\hline 1 & Rasa & 3,7139 & 3,1676 & 3,2890 \\
\hline 2 & Aroma & 3,1069 & 2,9769 & 3,1098 \\
\hline 3 & Warna & 2,9942 & 2,7601 & 3,2861 \\
\hline 4 & Kesegaran & 3,6705 & 3,1705 & 3,1676 \\
\hline 5 & Kandungan air & 3,3960 & 3,0809 & 3,0347 \\
\hline 6 & Harga & 3,2486 & 3,2283 & 2,5173 \\
\hline 7 & Tampilan fisik & 3,1908 & 2,7110 & 3,1850 \\
\hline 8 & Kemasan & 2,7283 & 2,2890 & 2,8786 \\
\hline 9 & Merek & 2,4566 & 2,2746 & 2,5954 \\
\hline 10 & Ketersediaan & 3,0607 & 3,2457 & 3,0058 \\
\hline
\end{tabular}

Tabel 5. Kualifikasi dan rentang skala

\begin{tabular}{cc}
\hline Rentang Skala & Kualifikasi \\
\hline $0<\mathrm{AB} \leq 3,2$ & Sangat Buruk \\
$3,2<\mathrm{AB} \leq 6,4$ & Buruk \\
$6,4<\mathrm{AB} \leq 9,6$ & Sedang \\
$9,6<\mathrm{AB} \leq 12,8$ & Baik \\
$12,8<\mathrm{AB} \leq 16$ & Sangat Baik \\
\hline
\end{tabular}

Tabel 6. Sikap terhadap atribut

\begin{tabular}{crcccc}
\hline \multirow{2}{*}{ No. } & \multirow{2}{*}{ Atribut } & \multicolumn{2}{c}{ Jeruk Lokal } & \multicolumn{2}{c}{ Jeruk Impor } \\
\cline { 3 - 6 } & Rating & Kualifikasi & Rating & Kualifikasi \\
\hline 1 & Rasa & 11,7642 & Baik & 12,2150 & Baik \\
2 & Aroma & 9,2490 & Sedang & 9,6620 & Baik \\
3 & Warna & 8,2644 & Sedang & 9,8394 & Baik \\
4 & Kesegaran & 11,6375 & Baik & 11,6269 & Baik \\
5 & Kandungan air & 10,4627 & Baik & 10,3056 & Baik \\
6 & Harga & 10,4874 & Baik & 8,1777 & Sedang \\
7 & Tampilan fisik & 8,6501 & Sedang & 10,1625 & Baik \\
8 & Kemasan & 6,2452 & Buruk & 7,8538 & Sedang \\
9 & Merek & 5,5878 & Buruk & 6,3759 & Buruk \\
10 & Ketersediaan & 9,9340 & Baik & 9,1998 & Sedang \\
\hline
\end{tabular}


Jurnal Teknologi Pertanian Vol. 22 No. 1 [April 2021] 69-80

Integrasi Sikap Multiatribut Fishbein dan House of Quality dalam Meningkatkan Daya Saing Jeruk Lokal [Kosasih dkk]

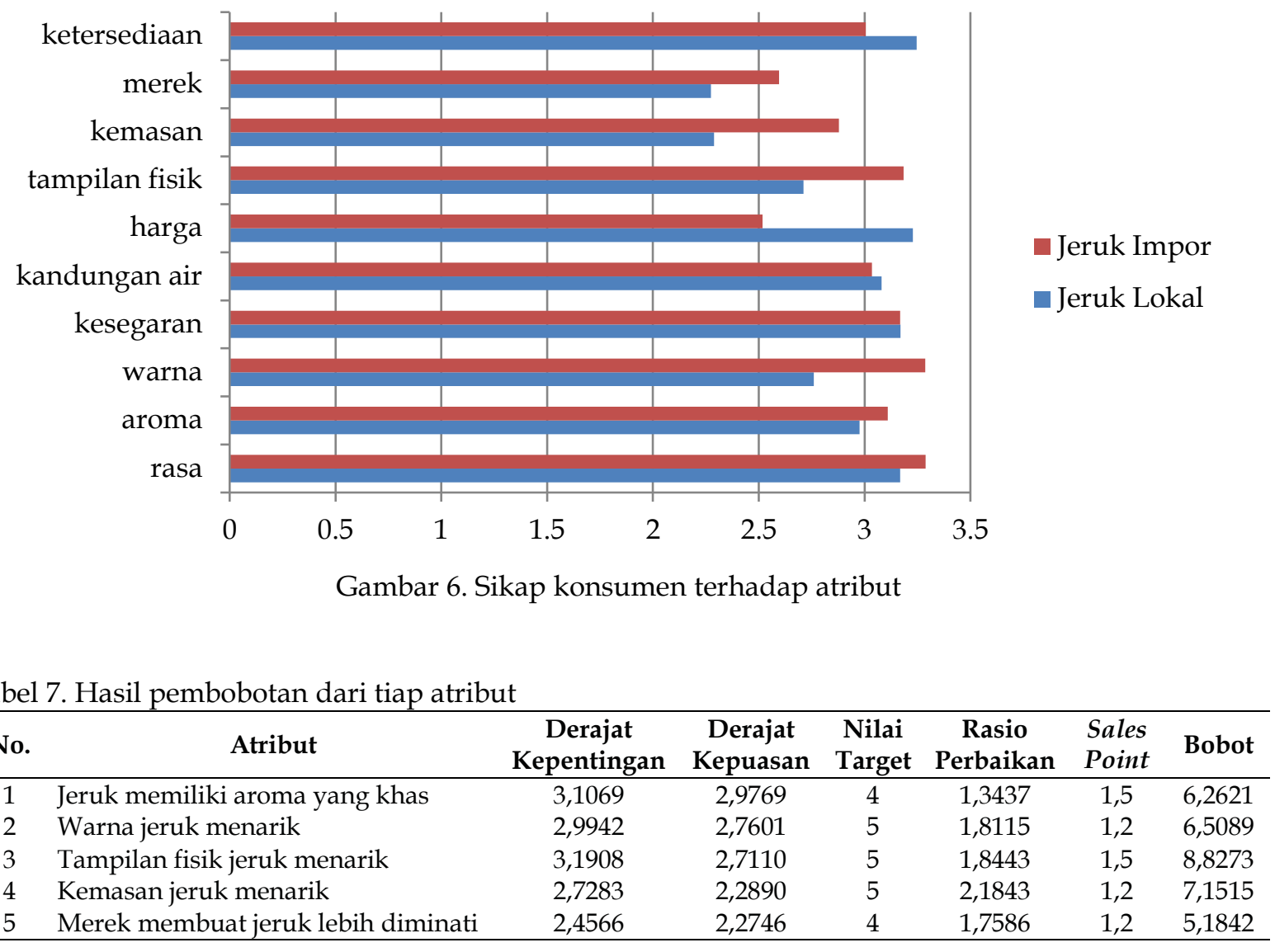

Tabel 8. Hasil pemeringkatan dari tiap respon teknis

\begin{tabular}{clccc}
\hline No. & \multicolumn{1}{c}{ Technical Responses } & $\begin{array}{c}\text { Absolute } \\
\text { Importance }\end{array}$ & $\begin{array}{c}\text { Relative } \\
\text { Importance }\end{array}$ & Rank \\
\hline 1 & Buah jeruk yang dijual sesuai standar matang & 75,89 & $15,92 \%$ & 2 \\
2 & Jeruk dipajang tanpa kemasan dan dikemas saat pembelian & 63,51 & $13,32 \%$ & 4 \\
3 & Pelilinan pada kulit jeruk (degreening) & 85,06 & $17,84 \%$ & 1 \\
4 & Tidak menjual jeruk lebih dari standar waktu & 39,25 & $8,233 \%$ & 6 \\
5 & Melakukan evaluasi terhadap tampilan fisik kompetitor & 8,827 & $1,851 \%$ & 9 \\
6 & Pembersihan, grading, dan sortasi & 32,74 & $6,868 \%$ & 7 \\
7 & Suhu buah selama penjualan tidak terlalu tinggi & 32,74 & $6,868 \%$ & 7 \\
8 & Mengemas jeruk dengan kemasan yang baik & 64,36 & $13,5 \%$ & 3 \\
9 & Pengepakan jeruk tidak terlalu padat & 27,72 & $5,813 \%$ & 8 \\
10 & Memberi label pada jeruk & 46,66 & $9,786 \%$ & 5 \\
\hline \multicolumn{2}{c}{ Total } & 476,76 & $100 \%$ &
\end{tabular}

\section{HASIL DAN PEMBAHASAN}

\section{Hasil Penyebaran Kuesioner}

Sebanyak 386 responden yang mengisi kuesioner, 24 responden berdomisili di luar Jakarta, 3 responden berusia kurang dari 16 tahun, dan 13 responden tidak memenuhi syarat, sehingga tersisa 346 responden yang digunakan untuk pengolahan dan analisis data lebih lanjut. Karakteristik responden hasil penyebaran kuesioner dapat dilihat pada Tabel 1. Berdasarkan hasil survei pertanyaan pendahuluan dari 346 responden yang mengisi kuesioner menghasilkan bahwa konsumen yang pernah membeli dan mengonsumsi jeruk baik lokal maupun impor lebih memilih jeruk impor dengan persentase sebesar $51,7 \%$. 
Jurnal Teknologi Pertanian Vol. 22 No. 1 [April 2021] 69-80 Integrasi Sikap Multiatribut Fishbein dan House of Quality dalam Meningkatkan Daya Saing Jeruk Lokal

[Kosasih dkk]

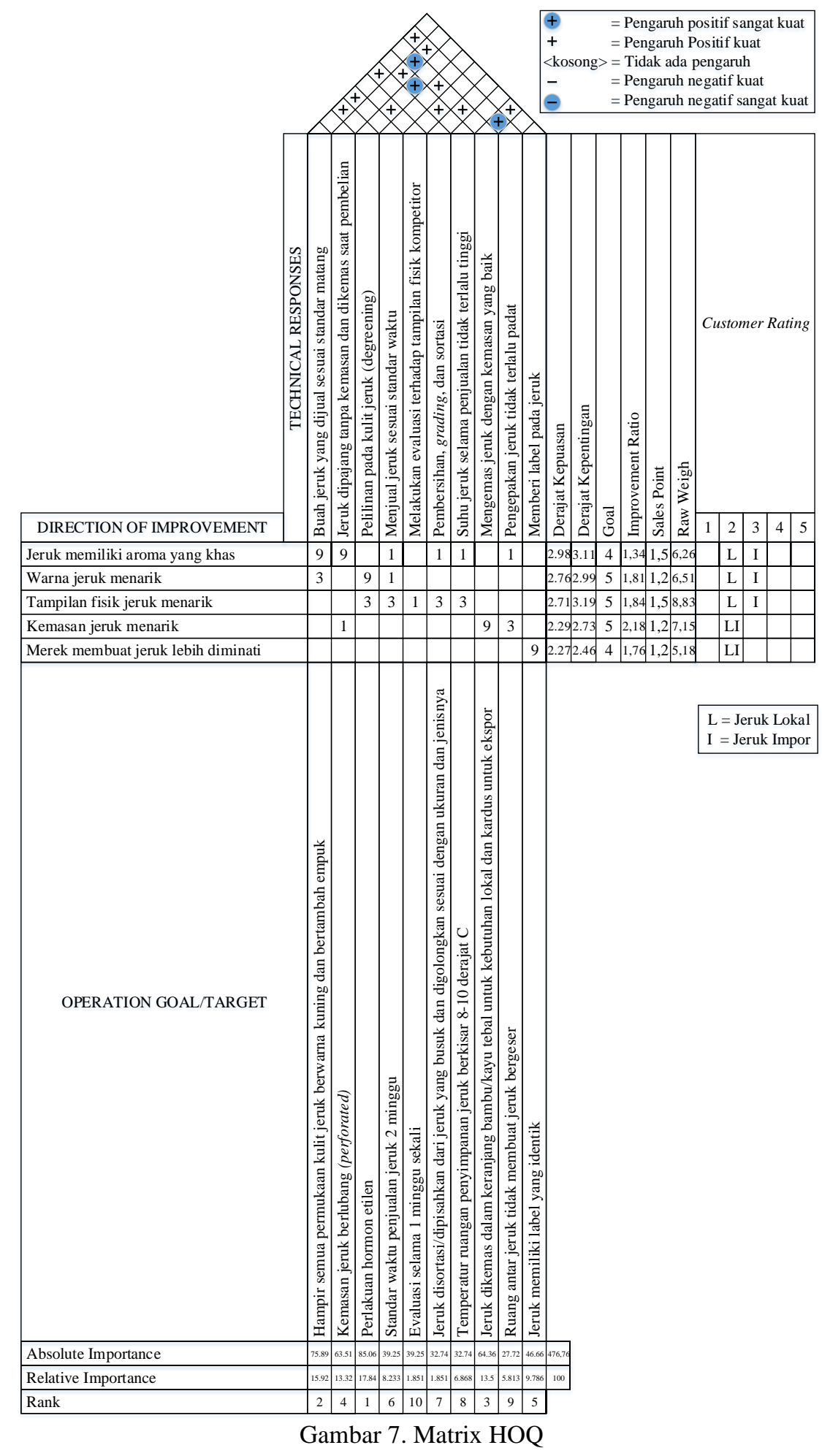

Jeruk impor yang paling sering dibeli adalah jeruk Sunkist, sedangkan jeruk lokal yang paling sering dibeli adalah jeruk Medan. Gambar 3 memperlihatkan jumlah pembelian 1-2 kg merupakan persentase terbesar dari jeruk dan jeruk impor. Diikuti jumlah pembelian 2-3 $\mathrm{kg}$ merupakan persentase terbesar kedua untuk jeruk lokal dan jumlah pembelian kurang dari $1 \mathrm{~kg}$ merupakan persentase terbesar kedua untuk jeruk impor.

Gambar 4 menunjukkan frekuensi pembelian lebih dari sebulan sekali merupakan frekuensi pembelian dengan persentase terbesar, diikuti frekuensi pembelian satu bulan sekali, 2-3 kali dalam satu bulan, satu minggu sekali, 2-3 kali dalam seminggu dan 
Jurnal Teknologi Pertanian Vol. 22 No. 1 [April 2021] 69-80

Integrasi Sikap Multiatribut Fishbein dan House of Quality dalam Meningkatkan Daya Saing Jeruk Lokal

[Kosasih dkk]

meningkat kembali pada pilihan lainnya dimana sebagian besar responden membeli jeruk dalam waktu yang lama untuk acara atau adat/tradisi tertentu. Sebagian besar responden membeli jeruk lokal di pasar tradisional dan membeli jeruk impor di Hypermarket, dapat dilihat pada Gambar 5. Ketersediaan jeruk impor biasanya banyak tersedia di Hypermarket dengan berbagai pilihan jenis walaupun sama-sama jeruk. Pada pasar tradisional yang kebanyakan pembelinya kalangan menengah ke bawah lebih banyak mencari jeruk lokal dibanding jeruk impor.

\section{Hasil Uji Validitas dan Reliabilitas}

Data hasil pengujian validitas dan reliabilitas untuk tingkat kepentingan atribut dapat dilihat pada Tabel 2. Data hasil pengujian validitas dan reliabilitas untuk tingkat kepercayaan jeruk lokal dan jeruk impor dapat dilihat pada Tabel 3. Pada Tabel tersebut data tingkat kepercayaan jeruk lokal dan jeruk impor terhadap atribut jeruk dinyatakan valid dan reliabel.

\section{Sikap Konsumen terhadap Atribut Produk Buah Jeruk}

Berdasarkan Tabel 4 dapat dilihat bahwa dari 346 responden diketahui bahwa konsumen percaya bahwa atribut jeruk lokal yang memiliki kinerja paling baik hingga terendah adalah ketersediaan, harga, kesegaran, rasa, kandungan air, aroma, warna, tampilan fisik, kemasan dan merek. Pada jeruk impor, konsumen percaya atribut dengan kinerja tertinggi hingga terendah adalah rasa, warna, tampilan fisik, kesegaran, aroma, kandungan air, ketersediaan, kemasan, merek dan harga.

Rentang skala digunakan untuk mengetahui sikap konsumen berada pada interval mana. Nilai interval yang diperoleh dari rumus rentang skala adalah 3,2 sehingga diperoleh nilai tabel rentang skala dan kualifikasi yang dapat dilihat pada Tabel 5 . Sikap konsumen terhadap atribut buah jeruk dapat dilihat pada Tabel 6. Sikap konsumen pada buah jeruk lokal menunjukkan bahwa keputusan konsumen di Jakarta untuk membeli atau mengkonsumsi buah jeruk lokal yang didasarkan pada ketertarikan karena harga, ketersediaan, kandungan air dan kesegaran. Hal ini menunjukkan bahwa buah jeruk lokal mampu memenuhi selera atau cita rasa konsumen dari buah impor. Sikap konsumen pada jeruk impor yaitu jeruk impor memiliki ketertarikan pada kemasan, warna, tampilan fisik, merek, rasa, dan aroma. Secara keseluruhan sikap konsumen dalam membeli dan mengkonsumsi jeruk, baik jeruk lokal maupun jeruk impor karena rasa, kesegaran dan kandungan airnya yang terkualifikasi baik. Atribut yang terkualifikasi buruk untuk jeruk lokal dan impor adalah merek, namun untuk jeruk lokal ditambah lagi dengan atribut kemasan.

\section{Posisi Daya Saing Buah Jeruk Lokal Dibandingkan Buah Jeruk Impor}

Konsumen buah jeruk berpandangan secara keseluruhan bahwa jeruk impor lebih unggul dibanding dengan jeruk lokal kecuali harga, ketersediaan, kandungan air dan kesegaran. Bahkan konsumen menilai kesegaran jeruk lokal (dengan rating 11,6375) hampir setara dengan kesegaran jeruk impor (dengan rating 11,6269), dapat dilihat pada Gambar 6. Bila dilihat frekuensi pembelian jeruk lokal lebih tinggi dibanding jeruk impor, namun konsumen lebih menyukai atau memilih jeruk impor. Salah satu faktor yang mempengaruhinya adalah faktor harga dari jeruk impor yang cenderung mahal. Ketersediaan jeruk lokal lebih banyak disebabkan karena distribusi jeruk lokal yang lebih luas ke segala kalangan. Menurut Jannah et al. (2018), ketersediaan buah jeruk impor dipasaran tidak seperti buah lainnya dari segi keberlanjutan.

Jeruk lokal didistribusikan dengan rantai pasok yang lebih panjang dibanding rantai pasok jeruk impor. Jeruk lokal melewati banyak perantara dari hulu ke hilir dimulai dari pengepul bibit $\rightarrow$ petani $\rightarrow$ pengepul $\rightarrow$ lapak $\rightarrow$ supermarket, distributor, pedagang kecil, pasar kecil, pedagang asongan dan ke daerah luar Jakarta sehingga ketersediaan jeruk lokal lebih luas dan banyak. Pada jeruk impor dari producer $\rightarrow$ international supplier $\rightarrow$ retailer $\rightarrow$ supermarket. Buah jeruk diimpor oleh supplier dan retailer tertentu dengan ketentuan khusus dan kebanyakan diimpor untuk supermarket sehingga keberadaan jeruk impor banyak ditemukan di supermarket.

Pendapat konsumen adalah buah jeruk impor memiliki kemasan yang menarik, warna yang seragam, tampilan fisik yang menarik, merek yang membuat lebih diminati, rasa yang lebih enak, dan aroma yang lebih wangi. Seperti jeruk Sunkist yang memiliki warna kuning yang seragam dan didukung permukaan kulit yang jauh lebih mulus dan lebih bersih, sehingga ketika dipajang di tempat penjualan terutama di toko khusus buah, 
Hypermarket atau pasar modern maka jeruk impor akan terlihat lebih menarik. Menurut Jannah et al. (2018), buah jeruk impor banyak dan mudah ditemukan di supermarket karena kualitas buah impor lebih baik dan harganya juga relatif terjangkau dibandingkan dengan jeruk lokal. Buah jeruk lokal dengan permukaan kulit yang tidak mulus, warna kulit yang tidak seragam walaupun jenisnya sama dan sehingga ketika dipajang terlihat kurang menarik ditambah dengan adanya bercakbercak hitam pada kulit jeruk lokal.

\section{Faktor-Faktor Pendukung dan Penghambat Daya Saing Jeruk Lokal}

Faktor pendukung daya saing jeruk lokal yaitu konsumen dengan rentang umur 36-45 tahun dan di atas 45 tahun lebih menyukai jeruk lokal. Daya saing jeruk lokal didukung pedagang jus dan kebanyakan pedagang makanan pinggiran menggunakan jeruk lokal sebagai sumber pembuatan minuman es jeruk atau jus jeruk karena kesegaran, kandungan air, harga, dan ketersediaannya. Faktor penghambat daya saing jeruk lokal yaitu faktor gaya hidup konsumen, dimana konsumen dengan tingkat ekonomi menengah ke atas kebanyakan berbelanja di swalayan dan membeli jeruk impor demi gengsi atau harga diri, karena lebih mewah dan bergengsi. Menurut Rosalina dan Zati (2019), alasan masyarakat cenderung membeli buah jeruk impor dibandingkan dengan jeruk lokal antara lain harga bersaing, gengsi, lebih menarik dari segi penampilan dan atribut.

Selain itu juga sebagian besar buah jeruk hasil petani skala kecil yang memenuhi pasar tradisional dan lapak pinggir jalan bermutu rendah. Menjamurnya pasar-pasar modern di Jakarta seperti Hypermarket, supermarket dan minimarket sehingga merubah gaya hidup dan cara pandang terhadap buah terutama terhadap standar keamanan buah dan mutu buah, khususnya jeruk. Selain itu, buah jeruk lokal diperdagangkan tanpa seleksi mutu pada tingkat produsen sehingga dalam pengiriman buah bermutu baik dicampur dengan buah bermutu jelek, daun dan ranting, bahkan buah busuk. Akibatnya kebanyakan buah bermutu rendah bahkan rusak dan harus dibuang.

\section{Matrix HOQ (House of Quality)}

Tabel 7 menunjukkan derajat kepentingan, derajat kepuasan, nilai target, rasio perbaikan, sales point dan bobot dari tiap atribut yang dikembangkan lebih lanjut menggunakan Matrix HOQ. Tabel 8 menunjukkan technical responses yang diperoleh dari hasil diskusi dengan pakar dilengkapi dengan hasil kalkulasi absolute importance dan relative importance. Nilai rank diperoleh dari nilai relative importance yang diurutkan dari nilai tertinggi hingga terendah. Gambar 7 memperlihatkan hasil dari analisis matrix $\mathrm{HOQ}$ secara keseluruhan.

Berdasarkan Gambar 7, atribut-atribut yang dikembangkan menggunakan Matrix HOQ terdiri dari lima atribut yang termasuk ke dalam kualifikasi sedang dan buruk. Kelima atribut tersebut adalah aroma, warna, tampilan fisik, kemasan dan merek.

\section{SIMPULAN}

Penelitian ini menyimpulkan bahwa atribut yang dominan mempengaruhi daya saing jeruk lokal yaitu harga, ketersediaan, kandungan air dan kesegaran. Posisi daya saing jeruk lokal rendah di mata konsumen dibandingkan dengan jeruk impor yang ditunjukkan dengan sikap konsumen yang lebih positif terhadap 6 dari 10 atribut jeruk impor lebih unggul dibanding jeruk lokal. Faktor pendukung daya saing jeruk lokal yaitu konsumen dengan umur 36 ke atas lebih menyukai jeruk lokal dan pedagang memilih menggunakan jeruk lokal dalam membuat minuman seperti jus jeruk. Sedangkan faktor penghambat daya saing jeruk lokal yaitu gaya hidup konsumen, jeruk hasil petani skala kecil bermutu rendah, jumlah pasar modern di Jakarta yang kian bertambah, dan rusaknya jeruk saat pengiriman karena jeruk bermutu baik dicampur dengan jeruk bermutu jelek. Atribut-atribut yang dikembangkan menggunakan Matrix HOQ yaitu lima atribut yang termasuk ke dalam kualifikasi sedang dan buruk, seperti aroma, warna, tampilan fisik, kemasan dan merek. Tindakan rekomendasi atau respon teknis yang diprioritaskan pada jeruk lokal dalam penelitian ini adalah pelilinan pada kulit jeruk (degreening), buah jeruk yang dijual sesuai standar matang, mengemas jeruk dengan kemasan yang baik, jeruk dibiarkan terbuka dan dikemas saat pembelian, dan memberi label pada jeruk. Implikasi dari studi ini memberikan rekomendasi bagi para pemangku kepentingan agar dapat bersamasama meningkatkan daya saing jeruk lokal. Di samping alasan yang telah disebutkan 
Jurnal Teknologi Pertanian Vol. 22 No. 1 [April 2021] 69-80

Integrasi Sikap Multiatribut Fishbein dan House of Quality dalam Meningkatkan Daya Saing Jeruk Lokal

[Kosasih dkk]

sebelumnya, penelitian ini difokuskan pada warga Jakarta karena masyarakatnya heterogen dan dianggap dapat mewakili perilaku konsumen Indonesia pada umumnya. Acceptance sampling untuk penentuan ukuran sampel tidak dihitung dalam penelitian ini. Hal tersebut dapat menjadi pertimbangan pada penelitian selanjutnya sehingga sampel dianggap dapat lebih mewakili populasi yang diamati.

\section{UCAPAN TERIMA KASIH}

Penelitian ini mendapatkan hibah dari Lembaga Penelitian dan Pengabdian Masyarakat, Universitas Tarumanagara. Pada kesempatan ini, Penulis menyampaikan ucapan terima kasih kepada semua pihak yang membantu dan memberikan wawasan dalam penelitian ini.

\section{DAFTAR PUSTAKA}

Ajzen, -I., Fishbein, -M., 1973. Attitudinal and normative variables as predictors of specific behavior. Journal of Personality and Social Psychology. 27(1), 41-57. http://dx.doi.org/10.1037/h0034440

Akao, Y. 1990. History of Quality Function Deployment in Japan, The Best on Quality. Hanser, New York

Badan Pusat Statistik, 2019. Statistik Hortikultura. BPS RI, Jakarta

Felixs,-D., Palit, H,-C, 2013. Analisa persepsi dan prefenensi kualitas buah tropis. Jumal Titra. 1, 77-82 http://publication.petra.acid/index.php/teknikindustri/article/view/140

Fishbein, M, Ajzen, I. 1975. Belief, Attitude, Intention, and Behavior: An Introduction to Theory and Research. Addison-Wesley, Reading, MA

Jannah, -N., Antara, -M., Effendy., 2018. Faktor-faktor yang memengaruhi perilaku konsumen dalam mengkonsumsi buah jeruk impor di kota Palu. Agroland. 25(2), 121-129. http://jurnal.untad.ac.id/jurnal/index.php/ AGROLAND/article/view/10885

Kosasih, -W., Soenandi, I, -A., Celsia, -E., 2013. Aplikasi QFD untuk pengembangan produk wafer (Studi kasus: PT Indo Sari Abadi). Jurnal Teknik dan Ilmu Komputer. 2(7), 258-269. http://ejournal.ukrida.ac.id/ojs/index.php/ JTIK/article/view/800

Munandar, J, -M., Udin, -F., Amelia, -M., 2004. Analisis faktor yang mempengaruhi preferensi konsumen produk air minum dalam kemasan di Bogor. Jurnal Teknologi Industri Pertanian. 13(3), 97-107. https://journal.ipb.ac.id/index.php/jur naltin/article/view/4537

Puspita, -W., Nugrahani, -R., 2014. Analisis sikap multiatribut fishbein mengenai atribut obat herbal merek tolak angin Sido Muncul di kota Bandung. Jurnal Sosioteknologi. 13, 15-24. https://doi.org/10.5614/sostek.itbj.2014.13.1.2

Rangkuti, F. 2002. Measuring Customer Satisfaction: Gaining Customer Relationship Strategy. Gramedia Pustaka Utama, Jakarta

Rosalina, -D., Zati, M, -R., 2019. Analisis daya saing jeruk lokal terhadap jeruk impor di kabupaten Tanah Karo. Jurnal Samudra Ekonomika. 3, 2633. https://doi.org/10.1234/jse.v3i1.1284

Sadeli, A, -H., Utami, H, -N., 2013. Sikap konsumen terhadap atribut produk untuk mengukur daya saing produk jeruk. Trkonomika. 12, 61-71. https://doi.org/10.23969/trikonomika.v12i1.460

Sasmaya, -I, Indriani, -Y., Gultom, D, -T., 2019. Perilaku konsumen dalam pembelian sayuran di pasar tradisional kota Metro. Jumal Ilmu Ilmu Agnibisnis. 7, 330-337.https://doiorg/10.23960/jïa.v73.330-337

Setyanto, L, -E, Arifin, -Z, Sunarti, 2017. Pengaruh atribut produk terhadap keputusan pembeli (survei pembeli Apple Iphone pada mahasiswa/mahasiswi S1 Fakultas Ilmu Administrasi Program Studi Ilmu Administrasi Bisnis angkatan 2013/2014 Universitas Brawijaya Malang). Jumal Administrasi Bisnis. 46, 19-27. http://administrasibisnis.studentjournalub.acid/i ndex.php/jab/article/view/1805

Siregar, S. 2013. Statistik Parametrik untuk Penelitian Kuantitatif. Bumi Aksara, Jakarta

Sunarjono, H. 2015. Berkebun 26 Jenis Tanaman Buah. Penebar Swadaya, Jakarta

Widiyanti, -W., 2019. Sikap konsumen terhadap multiatribut produk domino pizza dengan metode fishbein di Depok. Cakrawala. 19, 107112. https://doi.org/10.31294/jc.v19i1.4895

Yosini, -D., 2011. Consumer preferences on import and local fruit in Indonesia. Agron. Ser. Sci. Res. 54, 32-37. http://www.uaiasi.ro/revagrois/PDF/ 2011-2/paper/pagini_32-37_Yosini.pdf 